University of Warwick institutional repository: http://go.warwick.ac.uk/wrap This paper is made available online in accordance with publisher policies. Please scroll down to view the document itself. Please refer to the repository record for this item and our policy information available from the repository home page for further information.

To see the final version of this paper please visit the publisher's website. access to the published version may require a subscription.

\author{
Author(s): Mark Harrison \\ Article Title: The Fundamental Problem of Command: Plan and \\ Compliance in a Partially Centralised Economy \\ Year of publication: 2005 \\ Link to published version: \\ http://dx.doi.org/10.1057/palgrave.ces.8100110 \\ Publisher statement: "This is a post-peer-review, pre-copyedit version of \\ an article published in Comparative Economic Studies. The definitive \\ publisher-authenticated version, Harrison, M. (2008). The fundamental \\ problem of command: plan and compliance in a partially centralised \\ economy. Comparative Economic Studies, 47, pp.296-314 is available \\ online at: http://dx.doi.org/ 10.1057/palgrave.ces.8100110.
}




\title{
The Fundamental Problem of Command: Plan and Compliance in a Partially Centralised Economy*
}

\author{
Mark Harrison $\dagger$ \\ Department of Economics \\ University of Warwick, Coventry CV4 7AL, UK \\ and \\ Centre for Russian \& East European Studies \\ University of Birmingham, Birmingham B15 2TT, UK
}

\begin{abstract}
When a principal gives an order to an agent and advances resources for its implementation, the temptations for the agent to shirk or steal from the principal rather than comply constitute the fundamental problem of command. Historically, partially centralised command economies enforced compliance in various ways, assisted by nesting the fundamental problem of exchange within that of command. The Soviet economy provides some relevant data. The Soviet command system combined several enforcement mechanisms in an equilibrium that shifted as agents learned and each mechanism's comparative costs and benefits changed. When the conditions for an equilibrium disappeared, the system collapsed.
\end{abstract}

Keywords: Soviet economy, central planning, principal-agent problem JEL Classification: N44, P26

* Published in Comparative Economic Studies 47:2 (2005), pp. 296-314. This paper contributes to research on the political economy of the Soviet Union under Stalin funded by the Hoover Institution (principal investigator, Paul Gregory). I thank Leonid Borodkin, Paul Gregory, and Avner Greif for an inspirational conversation at Stanford University in July 2003, and Michael Ellman, Simon Ertz, Marshall Goldman, Paul Gregory, Gregory Grossman, David Lane, Peter Law, Valery Lazarev, Andrei Markevich, and Michael Waterson for comments and advice. I am responsible for errors.

$\dagger$ Address for correspondence: Department of Economics, University of Warwick, Coventry CV4 7AL, UK. Email: mark.harrison@warwick.ac.uk. I thank Leonid Borodkin, Paul Gregory, and Avner Greif for an inspirational conversation at Stanford University in July 2003, and Michael Ellman, Simon Ertz, Marshall Goldman, Paul Gregory, Gregory Grossman, David Lane, Peter Law, Valery Lazarev, Andrei Markevich, and Michael Waterson for comments and advice. I am responsible for errors.

First draft 10 November 2003. This version 14 June 2004. 
In The Economics of Planning Abram Bergson (1964: 327-9) distinguished between the economic merit and the rationality of socialism. The merit of socialism was to be gauged by the efficiency with which it satisfied consumer welfare. Its rationality could be measured not only against consumer welfare but also in relation to 'planners' preferences.' Rationality in either sense, he suggested, is best measured by 'the degree to which conduct conforms to the material ends sought ... We are thus led to ask, in respect to Soviet conduct regarding resource use, the cardinal question that arises in respect to economic conduct generally: In terms of what material ends and to what extent is such behavior economically rational?'

Few will have changed their minds about the merits of socialism as a result of the opening of the archives. The main advances that new documentation has made possible relate to the rationality of the Soviet command system. We can learn in unprecedented detail how Soviet officials behaved in the privacy of their offices and why they behaved as they did.

Specifically, we find that officials at each level were continually issuing new decrees and instructions to those below them, who rarely did exactly as they were told. At the time the same officials were receiving reports and information from below, some distorted and the rest incomplete; their core problem was to verify and control what people were really doing when they claimed to be obeying orders. The fact that officials at each level of the command system were not merely passive instruments of higher authority is what makes its operation an interesting problem.

How did Soviet officials command people and allocate resources? How did Stalin and his successors get others to do their bidding? This paper is about the rational behaviour of a principal who gives an order and the agent who is expected to carry it out. In studying the behaviour that we observe historically it tries to answer Bergson's 'cardinal question': 'In terms of what material ends and to what extent is such behavior economically rational?'

According to Avner Greif (2000), any institution that persists must be understood as an equilibrium of individual motivations and constraints: each person participates in it because it is in their interest to do, conditional upon their expectation that others have made the same calculation. How is the equilibrium of individual motivations and constraints achieved in the case of market institutions? Greif describes the fundamental problem of exchange as a game that arises from the sequential nature of a transaction. Two players contemplate a contract to engage in mutually beneficial exchange. The first player must initiate the contract and advance the means to fulfil it to the second player, or alternatively abstain. The second must decide to cooperate by completing the contract or cheat by stealing the proceeds of the exchange, including the advance, at the expense of the first player. Without means of enforcement the best strategy of the second player is to cheat and that of the first is to abstain. Historically, therefore, the rise of market exchange required the development of a variety of private and public enforcement mechanisms that overcame this problem.

Hierarchies give rise to a corresponding fundamental problem of command. The origin of the problem is the same, the sequential nature of a transaction. A principal gives an order to an agent and advances the means to implement it. Why is an order necessary? Because the principal desires an allocation of resources that differs from the one that would result from the agent's pursuit of her own self-interest; if this were not the case then the desired allocation would result from the agent's action without having to be told. It follows that for the hierarchy to find an equilibrium the obedient agent must be induced to forego opportunities for private gain. This problem must be solved for a hierarchy to find an equilibrium.

Hierarchies have existed in many forms and for many reasons. One form is the modern corporation. The transaction-cost approach of Coase (1937) and Williamson (1975) suggests that corporations exist in order to realise potential efficiency gains. In neo-Marxian economics, however, they exist to exert power and monopolise resources (Hymer, 
1960/1976; Marglin, 1974). In the first case the hierarchy grows because its superior efficiency gives it a competitive advantage, and society gains as a result. In the second case it grows by stifling competition and extracting a monopoly rent, while society suffers a welfare loss.

In this paper we will think about a particular kind of hierarchy, the command system. The command system is a hierarchy that is driven by monopolisation, not cost reduction: it attempts to monopolise a territory by force. Monopolisation is the strategy that Evgenii Preobrazhensky (1926/1965) advocated for the Soviet economy in the 1920s. We are also looking at something similar to Mancur Olson (1993) when he analyzed a proprietary dictator.

The problem that I describe is present in all complex hierarchical organisations, even where their existence is predicated on superior efficiency. This is because, even if an organisation exists solely to enable its members to exploit a mutual efficiency gain that is shared with society, any individual within the organisation can gain still more by shirking or cheating the other members. Such opportunities have always been present in command systems to the extent that their monopolizing drive was never completely successful and their control over resources remained partially, not fully centralised. We will use the Soviet economy as an example.

\section{The Fundamental Problem of Command}

In a market system each player's first option is to abstain. In a command system there is compulsion: to abstain is mutiny or desertion and these are punished. The agent can decide only to obey or disobey. Disobedience can take more than one form. Figure 1 illustrates the possible outcomes. The obedient agent receives the wage advanced $w$ and returns the planned output $x$ to the principal who gains a net surplus $x-w$. The disobedient agent may shirk, i.e. take the wage and ignore the command. The shirker's payoff is the wage plus the gain in reduced effort, $w+e$, which is always preferable to the wage alone, while the principal records a loss, $-w$.

\section{Figure 1. The Fundamental Problem of Command}

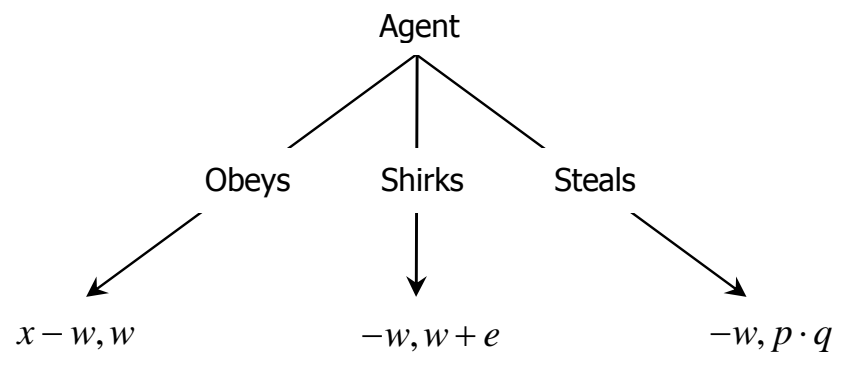

When the economy is only partly centralised the agent has an outside option: steal the wage advanced and invest it with a private network of persons outside the hierarchy. There are profit opportunities that the command system has left unexploited either by intention, just as a monopolist deliberately restricts supply and capacity usage, or by mistake because of plan errors. Where these opportunities exist, an unofficial network can move in and reap some of the gains privately. The agent stands to gain $p \cdot q$ where $q$ is the value of the agent's share in the opportunity and $p$ is the probability that she can realise it. In fact, $p$ measures horizontal trust or 'honour among thieves.' Where criminals mistrust each other crime cannot be organised and private networks will lack the scope to realise available opportunities. Also, where thieves lack honour the agent will not be able to enforce her share in the return from a private venture by private means; she will rationally expect others in the network to steal from her what she stole from the principal in the first place. 
The one-shot game has bad and less bad news for the principal. The less bad news is that the agent will prefer compliance to stealing while horizontal mistrust is high. The bad news is that, even if the agent will not steal, she will always shirk.

The news is better when the game is repeated. Suppose the principal responds to one-time disobedience by terminating the agent's position and expelling her from the hierarchy, so that she has nothing left to take into the horizontal network in the next round; then obedience is the agent's only move that can allow her to take part repeatedly and this is the principal's best hope. Repeated infinitely, obedience will return $w /(1-\delta)$ to the agent where $\delta$ is the discount factor and $1>\delta>0$. It follows that a forward-looking agent will prefer compliance to shirking where $w \cdot \delta /(1-\delta)>e$, and the latter is more likely the less the agent discounts the future.

Similarly the agent will prefer compliance to theft if $w /(1-\delta)>p \cdot q$. To draw out the intuition, compliance is more likely the higher is the official wage compared with unofficial profit opportunities, but even in the presence of a clear efficiency deficit that makes tempting private opportunities the principal can still keep the agent compliant provided honour among thieves remains low and the agent places a low enough discount on the future.

The fundamental problem of command can be interpreted broadly. The principal can be anybody who has a non-market relationship with an agent, from a great ruler to a lowly office manager. The unofficial network can be anybody external to the agent's hierarchy who may share the gain arising from the principal's loss: a principal in another hierarchy, a family friend, a criminal gang, or a foreign power. The asset of which the principal is cheated need not be understood as a narrowly material object. For example, the problem of command also describes the situation of a proprietorial dictator (Olson, 1993) who aims to monopolise the loyalty of the citizens; in this context the citizen's loyalty is a reproducible, transferable asset that the citizen may invest in the dictator, withhold, or transfer to the opposition (Wintrobe, 1990). These correspond to the agent's choices to comply, shirk, or steal.

\section{The Soviet Economy as a Command System}

The fundamental problem of command may be fairly obvious as a theoretical idea and yet have little or nothing to do with real life in a command system. In order to show a connection between history and theory I will use the Soviet economy to provide some data.

Some details of the Soviet command system are relevant. As Bergson (1964: 15-48) described it most enterprises were state owned and most producers were agents of a government principal, usually a minister acting as the legal fundholder. Horizontal relationships of specialisation and exchange were organised by order from above through vertical hierarchies rather than directly between buyers and sellers on a voluntary basis. Vertical subordination permitted orders to flow downwards on the basis of the information that flowed upwards.

The Soviet hierarchy was formed by a dictator, Stalin, who was unchallenged by his closest associates from 1932 until his death in 1953 (Davies, Ilič, and Khlevniuk, 2004). He ruled by decree: thus it was said that 'the plan is the law' (e.g. Gregory, 2003: 164). He ruled by delegation, so under him many smaller dictators exercised unconstrained power within the specialised fiefs that he allocated to them. Power cascaded downward through branching networks of agents that collectively formed the so-called nomenklatura, but in practice the 'big' nomenklatura of a million posts was fractionalised because every little dictator nested his own little nomenklatura inside the big one and demanded its loyalty (Khlevniuk, 2003; Lewin, 2003). 
Consequently, the Soviet state took the form of a nested dictatorship in which 'each organisation duplicated the administrative control structures of its superior in the vertical chain of command' (Gregory and Markevich, 2002.) The dominant administrative relationship at each level of the state was that of principal and agent, with each principal in turn acting as the agent of a higher principal until we reach the top where the great dictator ruled alone as capo di capi.

The Soviet command system was defined by hierarchical complexity: parallel hierarchies that were functionally differentiated at lower levels converged at the top in unified leading bodies such as the council of ministers and the politburo. To fulfil its function each specialised hierarchy had to trade horizontally with others. Thus the defence ministry purchased equipment and fuel from industry and food from agriculture; the ministry for engineering bought metals from the steel industry and power from the electricity generating industry. The coordination problem created by specialised hierarchies was solved only partly through centralisation. Rather there was 'centralised pluralism' (Nove, 1977: 60-4), meaning that much decentralised allocation went on behind a centralised façade (see also Zaleski, 1980; Markevich, 2003).

One reason for partial centralisation was the impossibility of forcing full information sharing in hierarchies. The process of reaching economic equilibrium in markets requires agents to share information. This sharing is voluntary and partial: voluntary because selfinterested, and partial because each agent does not need to know everything about all other agents for an equilibrium to result. According to Hayek (1945) economizing on informationsharing is one of the merits of the market system. In the Soviet command system, in contrast, the sharing of information was subject to coercion. Coercion arose because agents had incentives to conceal information rather than share it. The coercion was asymmetric: the principal had a right to know everything but the agent did not have a right to know anything. However, there were limits to the principal's coercion. The principal depended on the agent to select and aggregate information since he could not handle high-volume detail. The agent had self-interested motives to disclose information selectively and to distort it before disclosure. Thus, the principal could not trust what the agent told him, and did not know what the agent did not tell him, unless he could sought additional information by other means at additional cost.

Faced with this information problem, central authorities delegated responsibility for the detail of inter-ministerial exchange to ministerial officials. Such exchanges were authorised in high-level plans and decrees only in broad outline; then the ministries themselves had to negotiate detailed contracts for specific commodities that implemented the plan (Gregory, 2003). In principle, the implementation of contracts rested on budget authorisation by the ministry of finance and credit authorisation by the state bank. In practice, because the plan dealt only with aggregates and the budget dealt only with rubles, there were wide spheres of informal market allocation where firms competed for real resources with each other and with households (Harrison and Kim, 2004). Markets were wider for general-purpose intermediate products and consumables than for more specialised products such as special-purpose machinery where supply or demand were more easily monopolised. Whether or not competition existed, weak oversight promoted ministerial discretion and led to protracted inter-ministerial bargaining and disputes (Kroll, 1986; Harrison and Simonov, 2000; Belova, 2001a; Belova and Gregory, 2002).

It is well known that elements of market organisation persisted inside and alongside the command system. There were illegal markets for many industrial materials and consumer goods and services and legal markets for labour and labour-intensive foodstuffs (Katsenelinboigen, 1977). Historically these markets evolved in various ways. For the majority that escaped penal servitude the labour market remained relatively free but there 
were 15 years of much heavier regulation around World War II (Filtzer, 2002). At first the authorities tried to suppress the food market altogether, and they did achieve a broad state monopoly of grains and larger livestock, but the food shortages that resulted compelled them to concede legality to the market supply of backyard food products (Davies, 1994).

\section{Monitoring and Enforcement}

In the Soviet economy principals waged a continual struggle against shirking and theft. They also faced the fact that agents who intended to comply with orders did not always accept them unconditionally but sometimes tried to renegotiate them before complying. The authorities developed a wide range of mechanisms for monitoring and enforcement that secured the participation of the players in the command system. The outcome was an equilibrium of behaviours and expectations that secured the willing participation of all the players.

The need to solve the fundamental problem of command parsimoniously explains a number of Soviet economic institutions and suggests an agenda for more research. The development of several distinct mechanisms for monitoring and enforcement, each with different technologies, costs, and returns, implies that the dictator had scope to optimise on several margins at once. More research may lead us to a more unified explanation of the great shifts in Soviet reliance on propaganda and education, legal and relational enforcement, forced labour, secrecy, and military power, in terms of a general equilibrium rather than considering each in isolation.

\section{Multi-Layer, Multi-Stage Monitoring}

Information asymmetries pervaded the Soviet command system. Agents could exploit them at the expense of the principal, for example by persuading the principal that they had fulfilled an assignment when they had not (Harrison, 1998). If the principal could not tell whether he was receiving a yield of $x, 0$, or $-w$ he did not have much hope of solving the fundamental problem of command. Since the dictator could not trust agents in the direct line of command to tell the truth, he developed other means that met this need including separate hierarchies for planning and auditing (Gregory, 1990; Gregory, 2001; Belova and Gregory, 2002), financial and legal regulation (Gorlizki, 2002), contractual observance (Belova, 2001a), and so on. Thus, many agencies monitored activities, tracked outcomes, and reported to the boss.

Himself inscrutable and devious, Stalin required complete openness in those he allowed to report to him. He reacted severely to the least suspicion of a self-interested lie, more so if it appeared to involve horizontal collusion (Gorlizki and Khlevniuk, 2004). Stalin's mistrust of his own monitors was rational. The problem that resulted was: quis custodiet ipsos custodes [who watches the watchmen]? In the mid-1930s Stalin handed over the role of monitoring the monitors to the security 'organs' with results that are well known.

The authorities intensified monitoring by advancing $w$ in instalments and frequently checking progress. Breaking production and innovation cycles into many intermediate stages shortened the period over which an agent could behave badly before being expelled from the hierarchy. A by-product was the creation of sunk costs that, in a context of credit and fiscal centralisation, gave rise to Kornai's (1980) famous 'soft' budget constraint (Dewatripont and Maskin, 1995).

Multi-layer, multi-stage monitoring was costly. The centralisation of information that it required was only feasible within historical limits. Consider the information cost of monitoring a given outcome. Information costs fell rapidly in the nineteenth century and more rapidly in the twentieth century. However, the outcomes were changing too: the share of services in output was rising and there was growing variation in product and service quality (Harrison, 1998). Real output and value became harder to observe and accurately 
measure . As a result the viability of centralised, multi-layer monitoring followed an inverse U curve: it was more effective between 1870 and 1970, less before and less after (Broadberry and Ghosal, 2004).

\section{Enforcement Mechanisms}

Internalisation and Promotion. One way to achieve a command equilibrium was to persuade the agent to desire the same outcomes as the principal, that is to internalise the latter's valuations. Through schooling and the media Soviet leaders invested in persuading citizens to respect authority and adopt patriotic and party-minded norms. They developed costly rites of passage into citizenship, party membership, and military service, and also used humiliation rituals such as the 'boards of shame' that stigmatised bad citizens. They induced many to internalise preferences for the state to own basic industries, guarantee employment, social care, and minimum incomes, and protect the collective before the individual. These preferences typically outlived the emigration of individuals (Silver, 1987) and the demise of the system (Blanchflower and Freeman, 1997).

The promotion of Soviet values may be thought of as the costly creation of a costly moral identity, that of a loyal and obedient homo sovieticus, to which the citizen could subscribe through loyal activity, acquire a stake, and so gain access to a stream of psychological rewards. Having subscribed to this identity she then found shirking or stealing to be more costly than before since it triggered the loss of identity. There were innumerable ethnic, departmental, and campaign-oriented variations on the general theme: for example, Siegelbaum (1988: 210-46) has described how the state promoted the identity of a Stakhanovite worker in the late 1930s. There was a risk that the variation could become more important than the theme and weaken loyalty to the dictator beyond a point; thus Stalin acquired a rational mistrust of the ésprit de corps of the armed forces and aimed to destroy it in 1937.

It was possible to induce the agent to adopt the values of the principal by offering promotion in return for loyal behaviour. Then the obedient agent could hope to become a principal. A problem was that the number of aspiring agents tended to exceed the number of retiring principals. Under Stalin this problem was solved by frequent purges combined with ministerial subdivisions that created new leading positions in great numbers; 'I need not mention,' Stalin (1939/40: 650) reported, 'that the division of organisations has made it possible to promote hundreds and thousands of new people to leading posts.' But purges and reorganisations were also costly. Valery Lazarev (2005) suggests that the promotion mechanism eventually became unviable and threatened the command system with bankruptcy.

Artificial Punishment and Rewards. In the first turbulent years, the Stalinist leadership tried to run a high-employment, low-wage economy (Kuromiya, 1988) with predictable results: widespread shirking, demoralisation, and increasingly punitive reflexes. From 1931 onwards Soviet leaders tilted the balance of incentives towards compliance by supplementing $w$ with side payments to induce high effort that Bergson (1964: 72-92) described. They also threatened to cut or confiscate incomes altogether as the penalty for shirking and other disloyalty. They expelled non-compliant agents from the hierarchy by resort to firing and forced labour.

The efficacy of this route was limited for two reasons. One is that rewards and punishments were hard to target on effort with much accuracy. Effort was hard to monitor while output became harder to measure. The output-effort relationship in the 1930s and 1940s was dominated by random shocks. As a result the application of penalties for supposed shirking was also nearly random (Filtzer, 2002). Finally, the penalties available were very costly. After Stalin the credibility of punishment went into a long decline (Harrison, 2002). 
Another reason for limited effectiveness is that penalisation of some agents must be carried out by others who require a reward in return. Therefore, in any hierarchy the balance of rewards to penalties should rise as we ascend from one level to the next; a regressive distribution of managerial rewards for fulfilment is exactly what we see in the figures that Bergson (1964: 76) assembled. Given persistent labour shortage, however, it was often harder to find effective punishments for ordinary workers than for their managers. As a result, labour-management collusion pervaded the Soviet enterprise.

General Criminalisation, Selective Sanctions. Although the authorities could not eliminate the scope for the horizontal networks that threatened to corrupt official hierarchies, they could limit it. By criminalizing unauthorised transactions the authorities won a natural advantage in their struggle: they ruled out public enforcement of private deals so that agents who sought a return from diverting the principal's assets into the underground had to rely on relational enforcement alone. This nested the fundamental problem of exchange within the problem of command to the advantage of the principal.

Agents could enforce illicit transactions more easily when they were of low value, quickly sequenced, or based close acquaintance through the 'economy of favours' (Ledeneva, 1998). But the mistrust associated with the fundamental problem of exchange impeded large, long-range, unique, or complex deals and so eased the problem of command.

The authorities discriminated between two kinds of corruption. Disloyal agents took bribes for personal enrichment. Others extracted cash, resources, and favours from loyal motivations, for use in fulfilling plan assignments. Those who intended to comply with commands often had little alternative but to deal corruptly with external networks in order to carry them out (Belova, 2001b; Gregory, 2003: 164). Principals could control the balance between loyal and disloyal corruption by varying the tautness of plan assignments (Harrison and Kim, 2004).

When they detected illicit trade the authorities punished violations selectively, passing over the 'loyal' but corrupt transactions that were designed to promote fulfilment of the plan (Gregory, 2003) and bearing down more heavily on those that enriched the agent personally (Belova, 2001b). In turn, the risk premium that agents required for engaging in loyal trade should have been lower than for trade that lined their own pockets. By implication, the authorities discouraged disloyal networks while exploiting the networks of the loyal.

Heavy Defence Spending. This framework supports a simple interpretation of the domestic calculations behind foreign policy and military spending. Facing adversaries at home and abroad, Stalin did not fear them acting singly but he feared their combination (Khlevniuk, 1995, Simonov 1996). The potential for external foes to exploit internal treachery is portrayed in the fundamental problem of command as the scope for an agent to trade with a network representing a foreign power. From this point of view the powerful armed forces supported by a large defence industry described in recent work (Simonov, 1996; Barber and Harrison, 2000; Samuelson, 2000) drove down the chances of a deal between domestic and foreign agents by reducing both the reward that the foreign power would offer an agent and the probability that the agent could enforce the transaction privately and collect her reward from the foreign power.

By paying the soldiers and defence producers well Stalin was also able to raise $w$, the opportunity cost to his agent of collaboration with the enemy. Thus the scale of the defence effort and the privilege it gave to the servants of the military-industrial complex helped to solve the fundamental problem of command. This solution was very expensive, consuming a large share of national resources that was shrouded in state secrecy.

Secretiveness. The Soviet state carried secrecy to extraordinary lengths (Davies, 2001). Secrecy of economic information may have assisted principals in inhibiting the temptation to steal. A prerequisite for trade is the sharing of information: buyer and seller must be able to 
signal each other about ex ante supplies and demands (Hayek, 1945). When trade is between an agent in a hierarchy and an outsider, criminalizing the exchange of signals inhibits exchange by reducing information and increasing mistrust (Harrison, 2004). Unverifiable information reduced the probability $p$ of honour among thieves. Alternatively, the agent must incur extra costs to restore trust and ensure the credibility of the signals she sends and receives. This cost arises even when illicit signalling is not detected or punished.

Secrecy was costly in terms of enforcement and efficiency. Enforcement required the costly tracking of secret documents and further efforts to monitor and investigate cases of disclosure. The punishment of disclosure led to the loss of human capital already sunk in agents who turned out to be disloyal. Efficiency costs arose because secrecy created barriers to the sharing of information that could have led to efficient reallocations; for example, principals fixed the overall allocation of resources in ignorance of specific facts, while agents made specific allocations while insufficiently informed of the wider context. Thus secrecy also increased the probability of planning mistakes that lowered $x$ and raised $q$.

\section{Summary}

A range of enforcement mechanisms addressed the fundamental problem of command in the Soviet economy. Internalisation, promotion, and side payments and penalties controlled shirking. The criminalisation of disloyal networks, heavy defence spending, and secretiveness limited agents' trading at the principal's expense. But each was costly in different ways. The Soviet system combined them in a balance that shifted through time as principals and agents learned and the comparative costs of each mechanism changed. It seems that at the end of the 1980s the ensemble ceased to be viable and the system collapsed (Harrison, 2002). If the dictator had succeeded in optimizing simultaneously on each margin, one would expect that each mechanism failed at about the same time. This is roughly what is meant by the collapse of a system.

\section{Command and Negotiation}

In a speech to the sixteenth party congress in June 1930, Stalin (1930/1955: 357) defended the recent radical increases in final targets for the first five-year plan on the basis that he recognised the possibility of plan mistakes. The five-year plan was, he suggested

merely ... a first approximation, which has to be made more precise, altered and perfected in conformity with the experience gained in the localities, with the experience gained in carrying out the plan. No five-year plan can take into account all the possibilities latent in the depths of our system and which reveal themselves only in the course of the work, in the course of carrying out the plan ... Only bureaucrats can think that the work of planning ends with the drafting of a plan. The drafting of a plan is only the beginning of planning. Real guidance in planning develops only after the plan has been drafted, after it has been tested in the localities, in the course of carrying it out, correcting it and making it more precise.

At the time Stalin meant to encourage agents to make plans more ambitious, but in subsequent years he allowed his comments to be taken out of context and reinterpreted to sanction all kinds of plan modifications including the relaxation of targets when the plan turned out to be too ambitious (Harrison, 1985: 17).

In short, the ability to command well does not always accompany the power to command. So far I have assumed that (1) the principal was powerless to mitigate his plan mistakes that helped to form private profit opportunities and (2) the returns to different activities were common knowledge. However, it is normal that in hierarchies information is distributed unevenly. The principal has better general knowledge while the agent has the advantage in 
local knowledge. As a result, it was possible for a principal to make a mistake and an agent to know it. One way of raising returns in the command system was to let the agent bargain for an improved plan. The obedient agent could then choose to disobey, obey unconditionally, or bargain with the principal.

Figure 2. Unconditional and Conditional Obedience

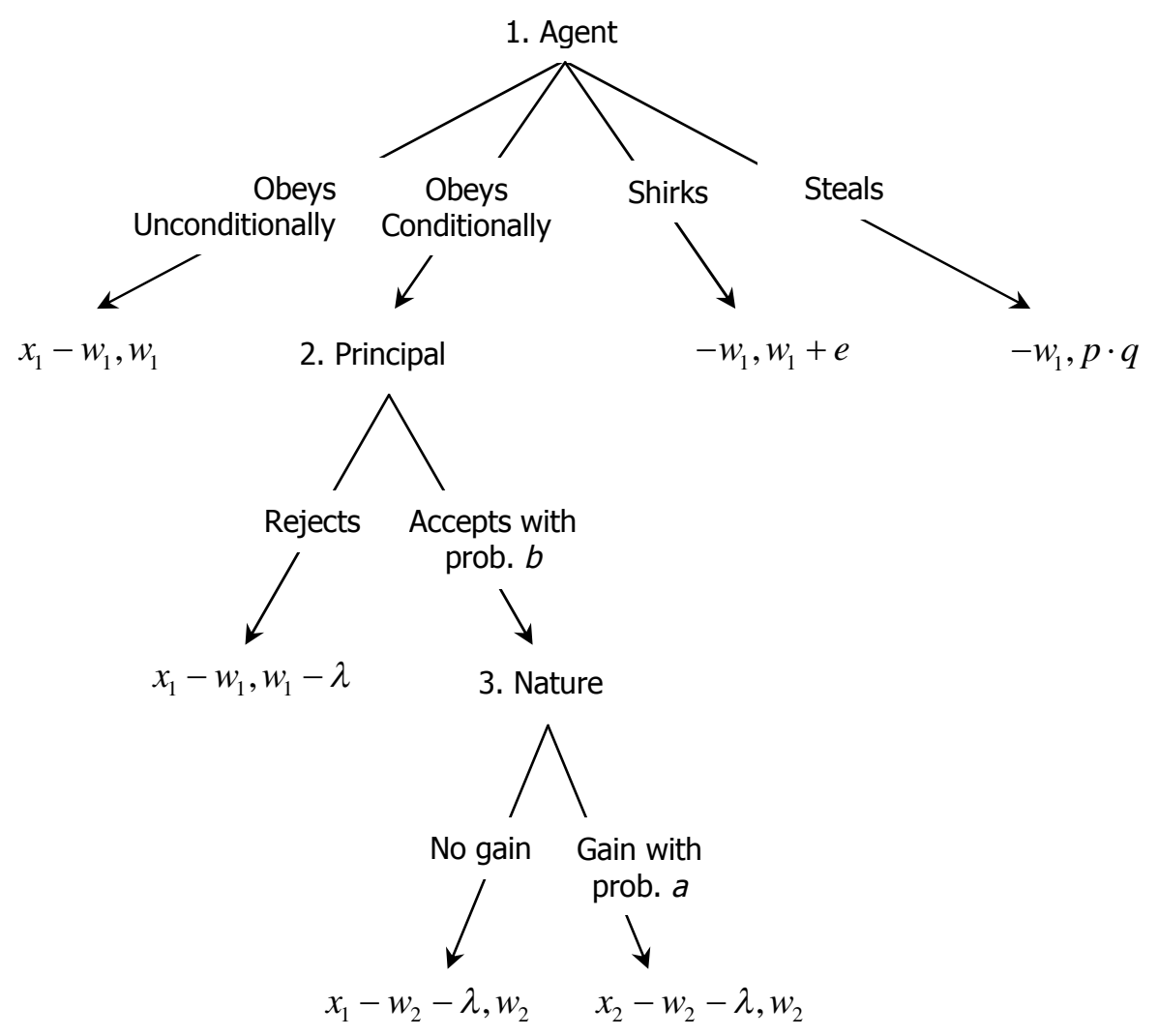

Vertical bargaining is shown in Figure 2. The agent offers to share information about plan mistakes and unexploited opportunities with the principal in return for a share of the principal's rent. Initially the principal advanced $w_{1}$ and expected to receive $x_{1}$. At stage 1 the agent chooses between disobedience and absolute and conditional obedience. Conditional obedience involves lobbying: the agent takes $\lambda$ from her advance and invests it in making the case for a better project that can yield $x_{2}$ for the principal and $w_{2}$ for the agent. At stage 2 the principal decides whether or not to accept the agent's case. If yes, at stage 3 nature takes a hand: it deals $x_{2}>x_{1}$ with probability $a$ and $x_{1}$ otherwise so $a$ is the probability that the original command was in error. The agent expects her lobby to succeed with probability $b$, which therefore measures the credibility of her case; if she succeeds, the agent's gain is that the principal will advance $w_{2}>w_{1}$ to her and also reimburse $\lambda$, the cost of lobbying. If lobbying fails the agent is worse off: she will get only the original advance and must pay the lobbying cost from it.

If we take into account that bargaining takes time and that the players may have preferences over the time it takes to reach a solution, the resulting problem begins to resemble Rubinstein bargaining with an outside option (Rubinstein, 1982; Shaked and Sutton, 1984); the outside option is the return to covert disobedience. This case differs in that, while the bargaining costs of principal and agent are fixed, who bears the cost is part of the bargain.

In Figure 2 the fundamental problem of command is mitigated as long as both principal and agent gain from plan renegotiation over unconditional compliance. The agent gains provided $b \cdot\left(w_{2}-w_{1}\right)>(1-b) \cdot \lambda$, i.e. the expected wage gain adjusted by the credibility of 
her information about plan errors exceeds the lobbying cost taking into account the probability that she will have to pay it. Thus, a 'listening' principal can reduce the relative attractions of shirking or stealing. However, listening is costly. The principal will gain only if $a \cdot\left(x_{2}-x_{1}\right)>\left(w_{2}-w_{1}\right)+\lambda$, i.e. his expected efficiency gain exceeds the compensation the agent extracts from him as a return on her successful lobbying, plus the deadweight cost of renegotiation. The larger are the probability of a mistaken command and the scope for mistakes, the greater will be the principal's gain.

Plan bargaining went on in the Soviet economy at every level. In the Politburo ministers lobbied Stalin to improve their shares of budgetary or material resources (Gregory, 2001: 224). At lower levels Bergson (1964: 81-2) noted the tendency of firms to complain of burdensome quotas or demand increased supply allocations as a condition for fulfilling them (see also Kornai, 1992: 121-4; Gregory, 2003: 202-4). Of course the agent preferred to tell the principal that the plan was too ambitious while the principal preferred to be told that the plan was too modest. In cases such as the counter-plan campaign of the early 1930s or the Stakhanov campaign a few years later (Kuromiya, 1988; Davies and Khlevniuk, 2002) the authorities organised countervailing pressure. The information advantage of the agent was greatest at the frontiers of military science and technology (Holloway, 1982; Holloway, 1984). In research and development the inventors' enthusiasm gave rise to strenuous competitive lobbying to boost plans (Harrison, 2003a). But when plans called for known advances to be applied to production the enthusiasm for higher plans disappeared (Berliner, 1976).

In the years of Stalin's dictatorship plan renegotiation remained informal. The post-Stalin economic reforms tended to institutionalise it. For example Kornai (1986: 1700) described Hungary in the 1980 s as:

a bargaining society, and the main direction is vertical, namely bargaining between the levels of the hierarchy, or between bureaucracy and firm, not horizontal, between seller and buyer. All issues ... - entry, exit, appointment, output, input, price, wage, tax, subsidy, credit, and investment - are subject to meticulous negotiations, fights, lobbying ... The Hungarian literature calls this phenomenon 'regulator bargaining'; it has taken the place of 'plan bargaining' which had prevailed in the command economy.

What has escaped analysis is why such bargaining was increasingly in the principal's interest. Planning was based on imperfect information. Conservative planning 'from the achieved level' (Birman, 1978), superimposed on growing complexity, gave rise to increasing misallocation. While faith in the system declined, agents' representations became increasingly persuasive and rent-sharing in return for information-sharing became increasingly formalised.

\section{Conclusions}

Abram Bergson sought to examine the rationality of the Soviet economic system according to various efficiency standards, including that of the system's directors. In terms of what material ends and to what extent was their behaviour rational? We have looked at Soviet institutions and behaviours from the point of view of a rational principal and agent in a command system that faces a problem. The fundamental problem of command is that of enforcement when agents may shirk or steal rather than comply. The equilibrium of the Soviet command system was conditional on finding solutions to this problem, and we have looked at some enforcement mechanisms that together may have provided the necessary conditions at the time but were also costly in different ways. This approach suggests that the system collapsed when the costs of enforcement could no longer be sustained. 


\section{References}

Barber, J and Harrison, M (eds). 2000: The Soviet defence-industry complex from Stalin to Khrushchev. Macmillan: London and Basingstoke.

Belova, E and Gregory, PR. 2002: Dictators, loyal and opportunistic agents: the Soviet archives on creating the Soviet economic system. Public Choice, 113(3-4): 265-86.

Belova, E. 2001a: Contract enforcement under dictatorship: the case of the Soviet economy PERSA Working Paper No. 14. University of Warwick, Department of Economics.

Belova, E. 2001b: Economic Crime and Punishment. In: Gregory, PR (ed). Behind the façade of Stalin's command economy: Evidence from the state and party archives. Hoover Institution Press: Stanford, CA. pp. 131-58.

Bergson, A. 1964: The economics of Soviet planning. Yale University Press: New Haven and London.

Berliner, JS. 1976: The innovation decision in Soviet industry. MIT Press: Cambridge, MA:

Birman, I. 1978: From the achieved level. Soviet Studies, 30(2):153-172.

Blanchflower, DG and Freeman, RB. 1997: The attitudinal legacy of communist labor relations. Industrial and Labor Relations Review, 50(3): 438-59.

Broadberry, SN and Ghosal, S. 2004: Technology, organisation, and productivity performance in services: lessons from Britain and the United States since 1870. CEPR Discussion Paper no. 4428. London: Centre for Economic Policy Research.

Coase, RH. 1937: The nature of the firm. Economica, 4: 386-405.

Davies, RW. 1994: Changing economic systems: an overview. In: Davies, RW, Harrison, M and Wheatcroft, SG (eds). The economic transformation of the Soviet Union, 1913-1945. Cambridge University Press: Cambridge. pp. 1-23.

Davies, RW. 2001: Making Economic Policy. In: Gregory, PR (ed). Behind the façade of Stalin's command economy: Evidence from the state and party archives. Hoover Institution Press: Stanford, CA. pp. 61-80.

Davies, RW, Ilič, M and Khlevniuk, O. 2004: The Politburo and economic policy-making. In: Rees, EA (ed). The nature of Stalin's dictatorship: the Politburo, 1924-1953. Palgrave: Basingstoke. pp. 108-134.

Davies, RW and Khlevniuk O. 2002: Stakhanovism and the Soviet economy. Europe-Asia Studies, 54(6): 867-905.

Dewatripont, M and Maskin, E. 1995. Credit and efficiency in centralized and decentralized economies. Review of Economic Studies, 62(4): 541-55.

Filtzer, D. 2002: Soviet workers and late Stalinism: Labour and the restoration of the Stalinist system after World War II. Cambridge University Press: Cambridge.

Gorlizki, Y. 2002: Industry, justice, and the politics of Soviet regulation. Paper to the Summer Research Euro-Workshop, University of Warwick, Department of Economics, 8 to 19 July.

Gorlizki, Y, and Khlevniuk, O. 2004: Cold peace: Stalin and the Soviet ruling circle, 19451953. Oxford University Press: New York.

Gregory, PR. 1990: Restructuring the Soviet economic bureaucracy. Cambridge University Press: Cambridge.

Gregory, PR. 2001: The dictator's orders. In: Gregory, PR (ed). Behind the façade of Stalin's command economy: Evidence from the state and party archives. Hoover Institution Press: Stanford, CA. pp. 11-33.

Gregory, PR. 2003: The political economy of Stalinism: Evidence from the Soviet secret archives. Cambridge University Press: Cambridge.

Gregory, PR and Markevich, A. 2002: Creating Soviet industry: the house that Stalin built. Slavic Review, 61(4): 787-814. 
Greif, A. 2000: The fundamental problem of exchange: a research agenda in historical institutional analysis. European Review of Economic History, 4: 251-84.

Harrison, M. 1985: Soviet planning in peace and war, 1938-1945. Cambridge University Press: Cambridge.

Harrison, M. 1998: Prices, planners, and producers: an agency problem in Soviet industry, 1928-1950. Journal of Economic History, 58(4): 1032-62.

Harrison, M. 2002: Coercion, compliance, and the collapse of the Soviet command economy. Economic History Review, 55(3): 397-433.

Harrison, M. 2003: The political economy of a Soviet military R\&D failure: steam power for aviation, 1932 to 1939. Journal of Economic History, 63(1): 178-212.

Harrison, M. 2004: Why secrets? The uses of secrecy in Stalin's command economy. PERSA Working Paper no. 34. University of Warwick, Department of Economics.

Harrison, M and Kim, B-Y. 2004: Plans, prices, and corruption: The Soviet firm under partial centralization, 1930 to 1990 . Working Paper. University of Warwick, Department of Economics.

Harrison, M and Simonov, N. 2000. Voenpriemka: Prices, costs, and quality in defence industry. In: Harrison, $\mathrm{M}$ and Barber, J (eds). The Soviet defence industry complex from Stalin to Khrushchev. Macmillan: London and Basingstoke. pp. 223-45.

Hayek, FA. 1945: The use of knowledge in society. American Economic Review, 35(4): 51930.

Holloway, D. 1982: Innovation in the defence sector. In: Amann, R and Cooper, J (eds). Industrial innovation in the Soviet Union. Yale University Press: New Haven, CT. pp. 276-367

Holloway, D. 1984: Stalin and the bomb: the Soviet Union and atomic energy, 1939-1956. Yale University Press: New Haven, CT.

Hymer, SH. 1960/1976: The International operations of national firms: A study of direct foreign investment. MIT Press: Cambridge, MA.

Katsenelinboigen, A. 1977: Coloured markets in the Soviet Union. Soviet Studies, 29(1): 6285.

Khlevniuk, O. 1995: The objectives of the Great Terror, 1937-1938. In: Cooper, J, Perrie, M and Rees, EA (eds). Soviet history, 1917-53: Essays in honour of R.W. Davies. St Martin's Press: London and Basingstoke. pp. 158-76

Khlevniuk, O. 2003: Sistema tsentr-regiony v 1930-1950-e gody. Predposylki politizatsii nomenklatury, Les Cahiers du Monde russe, 44(2-3): 253-268.

Kornai, J. 1980: The economics of shortage. Amsterdam: North-Holland.

Kornai, J. 1986: The Hungarian reform process: visions, hopes, and reality. Journal of Economic Literature, 24, 1687-1737.

Kornai, J. 1992: The socialist system: the political economy of communism. Clarendon Press: Oxford.

Kroll, H. 1986: Decentralization and precontract disputes in Soviet industry. Soviet Economy, 2(1): 51-71.

Kuromiya, H. 1988: Stalin's industrial revolution: politics and workers, 1928-1932. Cambridge University Press: Cambridge.

Lazarev, V. 2005: Promotion contracts and support for the Soviet regime. Comparative Economic Studies, this issue.

Ledeneva, AV. 1998: Russia's economy of favours: Blat, networking and informal exchange. Cambridge University Press: Cambridge.

Lewin, M. 2003: Rebuilding the Soviet nomenklaturas, 1945-1948, Les Cahiers du Monde russe, 44(2-3): 219-252. 
Marglin, S. 1974: What do bosses do? The origins and functions of hierarchy in capitalist production. Review of Radical Political Economics, 6(2): 33-60.

Markevich, AM. 2003: Was the Soviet economy planned? Planning in the People's Commissariats in the 1930s. PERSA Working Paper No. 25. University of Warwick, Department of Economics.

Nove, A. 1977: The Soviet economic system, London: Allen \& Unwin

Olson, M. 1993: Dictatorship, democracy, and development. American Political Science Review, 87(3): 567-76.

Preobrazhensky, EA. 1926/1965: The new economics. Oxford: Oxford University Press.

Rubinstein, A. 1982: Perfect equilibrium in a bargaining model. Econometrica, 50(1): 97110.

Samuelson, L. 2000: Plans for Stalin's war machine: Tukhachevskii and military-economic planning, 1925-41. London and Basingstoke: Macmillan.

Shaked, A and Sutton, J. 1984: Involuntary unemployment as a perfect equilibrium in a bargaining model. Econometrica, 52(6): 1351-1364.

Siegelbaum, LH. 1988: Stakhanovism and the politics of productivity in the USSR, 1935 1941. Cambridge: Cambridge University Press.

Silver, BD. 1987: Political beliefs of the Soviet citizen: sources of support for regime norms. In: Millar, JR (ed). Politics, work, and daily life in the USSR: A survey of former Soviet citizens. Cambridge University Press: Cambridge. pp. 100-41

Simonov NS. 1996: Voenno-promyshlennyi kompleks SSSR v 1920-1950-e gody: tempy ekonomicheskogo rosta, struktura, organizatsiia proizvodstva i upravlenie. Moscow: ROSSPEN.

Stalin, JV. 1940: Leninism. Lawrence \& Wishart: London.

Stalin, JV. 1955: Works, 12. Foreign Languages Publishing House: Moscow.

Williamson, OE. 1975: Markets and hierarchies: Analysis and antitrust implications. The Free Press: New York>

Wintrobe, R. 1990: The tinpot and the totalitarian: An economic theory of dictatorship. American Political Science Review, 84(3): 849-72.

Zaleski, E. 1980: Stalinist planning for economic growth, 1932-1952. London and Basingstoke: Macmillan. 